\title{
THE RELATIONSHIP BETWEEN HUMAN AND NON-HUMAN DIGNITY
}

\author{
Nico Vorster \\ School of Ecclesiastical Sciences \\ Northwest University
}

\begin{abstract}
In order to address the current ecological crisis, modern society requires an ethical and legal discourse that directs itself to the whole of creation, rather than only to human society's dependence on its natural environment or its survival. A conception of dignity is therefore needed that will be able to relate human and non-human dignity. This article proposes a multi-relational understanding of dignity based on a reading of the Genesis narrative, as well as other major themes of Scripture. It entails that human and non-human dignity ought to be understood and evaluated in terms of the dignity of the entirety.
\end{abstract}

Key Words: Human Dignity, Environmental Rights, Non-Human Dignity, Creation Narratives

\section{Introduction}

The ecological crises which we are currently experiencing are not just 'ecological' in nature, nor can they be solved by purely technical means. ${ }^{1}$ They not only demand an energy revolution, but also a moral and legal one.

Contemporary liberal human rights discourse seems to be inefficient in the face of the ecological threats that we are facing, because it is so formal in structure, so tilted towards individual entitlements, so engrained in modernity that the definitions of human dignity it issues are not adequate to address the global ecological crisis. Rights can, according to the general legal definition only be attributed to subjects of law who are rational beings that can grasp moral law and act as advocates for their interests. Little opportunity is provided for obligations to anything that is not free and rational.

Modern society requires an ethical and legal discourse that directs itself to the whole of creation, rather than only to human society's dependence on its natural environment or its survival - a discourse that correlates human dignity and ecological justice, human rights and the integrity of nature, and the rights of both present generations and future generations. In order to do this, a conception of dignity is needed that will be able to relate human and non-human dignity. Biblical literature and Christian ethics may be helpful in this endeavour because it poses no either/or choice between caring for people and caring for the earth, ${ }^{2}$ yet it gives dignity a multi-relational content and is focused on the well-being of the entirety. The aim of this article is to offer a definition of dignity that might help to relate human and non-human dignity to each other.

\footnotetext{
Jürgen Moltmann, Creating a Just Future (London: SCM Press, 1988), p. 53.

Cf. Dieter Hessel, 'Eco Justice after Nature's Revolt,' in Dieter T Hessel, (ed.), After natures revolt (Minneapolis, Mich.: Fortress Press, 1992), pp. 1-21, 11.
} 


\section{A Theological Perspective on Human and Non-human Dignity}

Modern environmental ethics holds different views on the question of whether nature has intrinsic value. The anthropocentric tradition maintains that only conscious agents possess an intrinsic value. Nature has value insofar as it is useful to human beings. The nonanthropocentric tradition argues that nature is valuable apart from its usefulness to humans

Through the ages the Christian tradition was largely influenced by the anthropocentric tradition. Christian theology has tended to over-emphasise human history at the expense of natural history, the transcendence of God at the expense of the immanence of God, and human salvation to the detriment of cosmic salvation. Certain strains of Christian theology developed a dualistic eschatology and anthropology which devalued the material world and the bodily realm. Spiritualist and ascetic Christian movements often proclaimed the cosmic homelessness of the human being thereby alienating humans from their environment, whereas some theologians gave modernistic interpretations of the cultural mandate found in Genesis 1 which exhibited confidence in unfailing technological and social progress. Yet the Bible itself, in my view, is not responsible for the ecological-crisis, but on the contrary, rather holds promise to address the ecological crises which we are currently experiencing. The main themes in the Bible provide Christians with creative tools to address the ecological crises and to resolve the tensions between human and non-human dignity.

\section{The Divine Origin and Interrelatedness of all Things}

In the creation narratives human beings as well as the natural environment derive their dignity from God who is the Origin and Sustainer of all life. God brought life into a state of total inhabitability by separating the chaotic and unfriendly elements from the friendly elements to create an environment in which humans and nature can live in peace and harmony.

The life-giving breath of God is the vital principle of life. In the Yahwist creation narrative humans receive life through a special act of God. God animates the human body with His divine breath. This serves as an affirmation of the ontological and sacred status of human life. The human being only comes to life because God breathes into him His own breath of life. When God withdraws His breath of life, everything returns to dust. The animal kingdom is also called into existence by divine breath, but only in the case of the human being reference is made to a direct transfer of the divine breath. Yet, the whole world is dependent on God constantly letting his breath of life go forth to renew the created order.

The transcendence of God must therefore not be emphasized at the expense of God's immanence. Creation has dignity because God dwells in it through His Spirit and sustains it. The special dignity of Creation lies therein that each living creature has been willed into existence by God and has an immanent quality bestowed by Him. ${ }^{3}$ Immanent quality means that living organisms achieve vitality when they serve the functions and ends that God assigns them. All organisms play their part in the complex of habitat. In the Priestly creation narrative emphasis falls on the fact that God created plants, trees and animals each according to its own kind. All things therefore received some unique quality that man must respect in his dominionship, because creation is an ordered totality that comprises a complex variety. 
According to the Priestly creation narrative human beings are created on the same day as the animals. Both proceed from the earth and in their nature and existence belong to it. It is an important testimony to the intimate relation between human and non-human creatures. The narrators show thereby that animals and humans belong together and share a common environment and living space. The older Jahwist account presents the same view by emphasizing that human beings are, like animals, living creatures. The human environment is immersed in the natural environment.

Everything exists, according to the creation narratives, through God and in God. The Spirit of God is present everywhere and sustains, nourishes and gives life to all things in heaven and on earth. God reveals Himself in the structure of the world and has imprinted in His individual works marks of His glory. Nature has an inherent dignity because it mediates awareness of the divine.

The divine origin and interrelatedness of all things underlies the biblical concept of the human being. The Priestly narrative describes the human being as created in the image of God. Various interpretations of the meaning of the human being's image are possible. If Genesis 1:26 is taken as premise, the image can be related to the human being's representation of God on earth. The interchangeable use of děmût en sélém makes it possible to define this representation either as a reflection of God's virtues (děmût), or as a similarity between the ontological and physical characteristics of God and the human being (sélém). If Genesis 1:27 is taken as premise the image can be understood as existing in the human being's createdness as male and female. When verses 26 and 27 are read together the image might indicate that the human being exists in a singular and plural manner, thereby reflecting the existence of God. It is also possible, on the basis of verse 28, to understand the essence of the imago Dei as existing in a combination of the human's createdness as male and female and their task to rule.

The nature of this article does not allow an extensive discussion on this issue. Suffice to suggest that Genesis 1:26-28 gives a cautious and open meaning to the human being's image. Through the interchangeable use of demǔt and sélém it attempts to relate the human being to God, but at the same time it also emphasizes the innate difference between God and the human being. The human being's image contains both a relational element and a hierarchical and biological component. It signifies the relation between God, the human being and creation, yet these relationships are also hierarchical in nature.

The Imago Dei firstly refers to the capability of the human being to have a relationship with God, fellow-human beings and the natural environment. It emphasizes that human beings are God's representatives on earth and are endowed with a special status of dignity. The dignity of humankind is not based on something intrinsic to their nature, but lies in their relation to God. The image of God is applied to humans only, never to animals. This is of crucial importance for understanding what makes humans different from animals. The human creature is called to enter into a conscious communion with God, while there is no such relationship between God and the non-human realm. The human's image of God refers to those special dimensions of human nature that elevates humans above the animal plane, such as personhood, self-awareness and self-determination. ${ }^{4}$ Human beings are thus unique among God's creatures, but they also form part of the entirety of creation.

The human being's createdness as male and female is closely related to the human's relationship with God. In the same way that God has the ability to deliberate with Himself,

4 Cf. Bernhardt W Anderson, From creation to new creation. Old Testament perspectives (Minneapolis, Mich.: Fortress Press, 1994), p. 12. 
that is, to be singular, yet at the same time plural, the human being is created singular, as a human being that shares a common humanity - but also plural as male and female that are sexually differentiated. Likeness to God cannot be lived in isolation. The human being is created as a social being. Interhuman communication, forming relationships, the ability to love, associate and express, are all reflections of the virtues of God Himself. The deliberative quality of God, which is transferred to human beings, allows people to deliberate about the usefulness of other species in relation to human ends, but this must be done in a way that respects God and the well-being of His creation.

Though personhood, self-awareness and self-determination are also considered as important in liberal human rights discourse, there is a distinct difference between the Christian and liberal philosophical understanding of these human attributes and their ethical application thereof. In liberal rights discourse personhood, self-awareness and self-determination are based in the autonomous nature of the rational human being and are, therefore, understood in an anthropocentric sense as qualities that grant humans the right to be free of external constraint. In biblical literature personhood, self-awareness and self-determination have a theocentric origin and are inextricably linked to humans' ability and responsibility to respond to God and their environment. These are created attributes that the human needs in order to relate to God and the environment, and they serve the function of engagement, not disengagement.

Secondly, the Imago Dei possesses a biological and hierarchical component. Genesis 1:28 charges human beings to exercise dominion over the non-human realm as God's representtatives on earth. Though the Hebrew verbs used in Gen 1:26-28 for dominion have a violent meaning in other contexts, ${ }^{5}$ the intention of Gen 1:26-28 clearly is that humans must exercise their dominion over the earth within limits, that is, in responsibility to the Creator and in a way that will enhance the Creator's earth and all its creatures. ${ }^{6}$ This is affirmed in Genesis 2:15 where the humans' responsibility towards creation is depicted as taking care. Passages in the Pentateuch also contain various laws aimed at the protection of the environment. ${ }^{7}$

From the abovementioned it becomes clear that the value of human beings and the nonhuman realm lies in its relatedness to God. Moltmann ${ }^{8}$ rightly states with regard to human dignity, "The dignity of human beings is unforfeitable, irrelinguishable and indestructible, thanks to the abiding presence of God".

Dignity is a multi-relational term. Here the Judeo-Christian tradition and the classicliberal tradition part ways. The Enlightenment based human dignity in intrinsic qualities of man such as rationality with the result that dignity received a foundation in the bearer himself. The weakness of this tradition is that it tends to overemphasise the autonomy and independence of the individual at the expense of the social and natural dimensions of human life. This happens because this line of thought seeks to preserve human dignity by protecting the independence of the human being, without sufficiently realising the importance of relationships for human dignity. The Biblical tradition, in contrast, cements human dignity in a status that God bestows upon the human being within a specific relational structure. Human dignity therefore has two main features: Firstly it is inviolable

Cf. Joel 3:13, Jer. 34:15.

Cf. Walter Bruegemann, Theology of the Old Testament (Minneapolis, Mich. : Fortress Press, 1997), p. 461. Ex 23:10-12, Lev 26:34, Deut 20:15, 19-20, 22:6, 25:4.

Jurgen Moltmann, God in creation - a new theology of creation and the Spirit of God. (Minneapolis, Mich.: Fortress Press, 1993) p. 233. 
because it is God-given. Every human being has an entitlement to respect. This implies that state authorities have to respect this entitlement in itself and to protect it where it is threatened or disregarded. ${ }^{9}$ It also implies that human beings have a fundamental right to self-determination and self-realisation. Secondly, human dignity is an ethical category that involves rights but also duties, because the human being is an individual in communion with fellow human beings and the environment. The Christian image of man sees the individual never as the mere bearer of interests and intentions, but always as part of an interwoven structure of relationships and responsibilities, regardless of whether the individual is aware of this structure or not. ${ }^{10}$ Future rights discourse will have to place more emphasis on duties, especially on the duties of humans towards the environment, in order to address the ecological crisis.

Since the human being's dignity is exercised within a God-given relational structure, the state needs to protect the relational structure itself into which the human being is born. The social dimensions of human relationships, as well as the relationship between the human being and the natural environment, must be guarded because the human being is dependent upon these relationships. Humans therefore have a right to development such as exercising culture, having children, forming families and obtaining an an education. They also have environmental rights such as access to food, water, and a clean and healthy environment. If the state does not protect the relational structure into which human beings are born, individual dignity will ultimately vanish because dignity can't survive if the God-given relational structure is annihilated.

\section{Sin and the Covenant}

Genesis 1:26 defines the appropriate nature of humanity in the world, whereas the rest of the primeval narrative demonstrates the human being's misuse of the rule that the image of God conferred on him. In the narrative of the Garden of Eden the human couple rebels against God by trying to be like Him. This disrupts their relationship with God, each other, non-human creation and the soil on which they depend for their existence - the relational structure that God created has become distorted. Humankind's sin leads to a return to chaos. In the Priestly narrative the flood is portrayed as a return to the initial watery chaos that characterised the uncreated world.

God makes a new beginning with humankind by entering into covenant relationships with His people. The history from creation to Exodus-Sinai is divided into a sequence of covenants, each of which is declared an everlasting covenant. The first period extended from creation to the Flood and is concluded by a covenant between God and Noah. This covenant is not only universal in that it embraces all peoples, but it is also an ecological covenant that includes the earth itself and all of its inhabitants. It reaffirms the creational doctrine that God is committed to the preservation of creation. Because God commits Himself to creation, humans will fulfil their destiny by also committing themselves to the created world. While God makes a covenant with all living human beings in Genesis 9, human beings and animals are not assigned the same value. Human beings may not kill each other, but God gives them permission to eat animals. Though the ecological covenant

9 Bernhard Vogel et al, Human dignity. Christian responsibility as a basis for the practice of politics. (Berlin: Konrad Adenheuer Foundation, 2007), 20.

$10 \quad$ Ibid, 28. 
affirms the intrinsic value of all creatures, it does not mean that all beings have the same status before God. ${ }^{11}$

Both the Abrahamitic and Sinaitic covenants contain a strong ecological motive. They emphasise the importance of land as a gift of God. The gift of land is seen in the Old Testament as an expression of God's covenantal love and faithfulness. Many texts in the Old Testament reflect the close relationship between the people and the soil - land is treated as part of the covenantal community: If the people obeyed God the land would flourish, but when the Israelites spurn the worship of JHWE and neglect the demands of divine justice, the effects would also impact on the land. The importance of land for human welfare is furthermore clearly illustrated in passages of the Torah, which contain environmental laws that are aimed at protecting the land. ${ }^{12}$ These commands flow from the sense of covenant community and respect for each other as beings in the image of God.

The Sinaitic covenant proclaims a strong Sabbath ethic that is also applied to the land. The aim of the Sabbath ethic is to protect the created relational structure. Human intervention with nature ought to cease for the duration of the Sabbath. In the seventh year Israel has to leave the land untouched. The goal is twofold: the poor have to be provided the opportunity to assemble food from the lands and the land itself has to rest. In Leviticus 25 the commandment contains a warning: If the people do not obey the rule of the Sabbath year, God will exile the people from His land so that the land can recover and celebrate its Sabbath with God. In this case, the integrity of the land is considered more important than the rights of the peoples. The decline of the ecology is seen as a result of human injustice.

Future generations also share in the created relational structure. Every covenant in Scripture assumes responsibilities towards future generations, because the covenants are made 'with you and your offspring' forever. ${ }^{13}$ This refrain frequently recurs in the Old Testament and establishes a trans-generational continuity, a set of obligations that link past, present and future.

\section{The Cosmic Dimension of Redemption}

Traditional theology often emphasised the personal dimension of God's redemption at the expense of the cosmic dimension by focussing exclusively on God's history with humanity, whereas the natural world was regarded as a stage for the divine-human drama. ${ }^{14}$

However, the cosmic dimension of God's redemptive work is affirmed both in Old and New Testament literature. Old Testament prophetic-eschatological literature expresses it through the word shalom. ${ }^{15}$ God will create a condition of peace on earth by transforming people, relations between Israel and the nations, and nature itself. In Deutero-Isaiah the universal liberation that God brings is founded in the concept that God is not only the Redeemer of Israel, but also the Creator of Heaven and earth. ${ }^{16}$ The non-human realm will, therefore, also share in God's eschatological promises.

11 Cf. John B Cobb, 'Postmodern Christianity in quest of eco-justice', in Dieter T Hessel, (ed.), After natures revolt (Minneapolis, Mich.: Fortress Press, 1992), pp. 21-40, 33.

12 Cf. Ex 23:12, Lev 25:4-8, Ex 23:10.

13 Gen 3:15, John Nash, Loving nature. Ecological integrity and Christian responsibility (Nashville, Tenn: Abingdon Press, 1993), p. 101.

14 Paul H Santmire, 'Healing the Protestant mind: Beyond the theology of human dominion,' in Dieter T Hessel, (ed.), After natures revolt (Minneapolis, Mich.: Fortress Press, 1992), pp. 57-79, 57.

15 Isaiah 11:1-9, Esec 34

16 Isaiah $42: 5,44: 25$. 
The New Testament portrays Christ as not only the Saviour of humankind, but also the cosmos. His incarnation confers dignity not only on humankind, but on all earthly and material things, because by becoming flesh Christ indicates that the material world is part of His salvational work. According to the Gospels Christ is the mediator of creation who brings God's Kingdom to earth. ${ }^{17}$ God's Kingdom is portrayed as a future reality that is also a present reality, since the revelation of Christ is the revelation of the Kingdom. Christ's rule over all things has already started and has cosmic implications for the present. Christians, therefore, cannot abandon this earth, because Christ came to renew this earth as our final destination.

In Pauline literature the final fulfilment has an integrative function in the sense that the whole of creation is destined for redemption and included in God's final aim. In Colossians 1:20 and Ephesians 1:10 Christ is depicted as the firstborn of all creation and the reconciler that holds all things together. Christ is the Foundation of all things, reconciling all things in heaven and on earth with God. He died not only for humankind, but for all beings. By conquering sin He restores human relationships with God and with nature and salvages the relational structure of creation as a whole.

Since God is the Origin of all things and all things are interrelated, God's salvation will not be fully accomplished if His redemptive work does not extend to the whole of creation. As long as creation is unredeemed, Christians will suffer affliction. In Romans 8 the destiny of creation is bound to the destiny of humanity. The whole of creation is portrayed as groaning in travail, awaiting liberation from futility and decay. It expects redemption from the powers of $\sin$ and death which have already been experienced by believers who received the first fruits of the Spirit. This does not mean that all creatures will partake in the same glory as the children of God, but that they will share in the better state in their own way.

Romans 8 portrays God as immanently involved in creation through His Spirit, though still distinct from it. The Spirit leads Creation to its purpose, namely its redemption and perfection, with the result that creation becomes an instalment of the future and the embodiment of promise. An eschatology that takes into account the cosmic dimension of God's redemptive work and God's immanent involvement in creation can never support the notion that the cosmos is not really our home. It will always create cosmic optimism since the earth is embedded in a meaningful rather than a pointless purpose.

\section{Translating Christian Principles to the Public Realm}

The current ecological crisis is of such magnitude that the mere propagation of a new lifestyle will not suffice. Political and legal reform are needed to establish legal rules for relationships to muster sufficient power in order to address the current scale of the ecological crisis. Stephen Toulmin ${ }^{18}$ rightly states that instead of viewing the world of nature as onlookers from outside, we now have to understand how our human life and activities operate as elements within the world of nature. Political and legal reform is needed to establish legal rules for relationships that will muster sufficient power to address the current scale of the ecological crisis. Human rights discourse will have to accept that human beings are not masters of the environment, but participants in the eco-system and that human justice depends on ecological justice. It will have to address the inherent

7 Cf. John 1:1-3, Mat 4:17.

18 Stephen Toulmin, The return to cosmology: Postmodern science and the theology of nature (Berkeley: University of California Press, 1982), 217-274, 255. 
conflicts between the interests of present generations and those of the future, between human well-being and the protection of nature, and between local and global concerns.

The much debated question of whether an environmental ethic should be based on human needs or upon nature itself is a false question. Human needs and the integrity of nature are interdependent. It therefore seems as if the human rights discourse will have to part ways with the Kantian grounding of rights and intrinsic value in the autonomy and rational consciousness of human beings. Though human consciousness is a source of values, it does not mean that it is the locus of value. ${ }^{19}$ Human needs and the integrity of nature are interdependent. Rights need to be defined multi-relationally in the light of the relational structure of which human beings are the most important part. The value of human beings lies in their relatedness to God. This presupposes certain inviolable entitlements and correlating duties. Human beings are, however, also participants in a divinely created relational structure whose maintenance is a prerequisite for the realisation of human dignity. Humans therefore have natural rights to use natural resources to satisfy human needs, but also the moral responsibility to safeguard the relational structure that God created. This entails that humans must care for, and nurture, the natural environment.

The definition of human dignity as a multi-relational term might help to resolve the impasse between the anthropocentric and non-anthropocentric tradition in environmental ethics. Gustafson ${ }^{20}$ states an important ethical principle in this regard: "Nature is a multidimensional source of values, and its values are specified in relation to other things, other values that we cherish."

In other words, the value of nature's parts are measured in relation to other parts of nature, as well as in relation to the values that human beings cherish as a result of their deliberation. The well-being of the entirety is ultimately a prerequisite for the realisation of individual liberties.

If the rights of human beings and the integrity of the environment are not continuously balanced, human development will become unsustainable. However, two fundamental issues need to be addressed: How should people accord dignity to non-human species? How might a revised framework of human rights grant nature's creatures due respect?

\section{How to Grant Dignity to Non-human Species?}

The non-anthropocentric notion of 'rights of nature' creates many moral and juridical difficulties. From a moral perspective it is clear that nature and animals cannot be granted the same rights as humans. If so, human civilisation itself would become impossible. Biotic egalitarianism is simply not tenable because we can't do away with the food chain. The recognition of non-human rights will, furthermore, make judicial adjudication extremely difficult and complex, because it is not easy to define the scope and content of such rights.

The anthropocentric notion of human dignity that bases rights in the autonomous rational nature of humans is also insufficient, because it tends to reduce nature to a mere means, while human beings are the measure of all things. Anthropocentric values are of

\footnotetext{
19 Cf. Holmes Rolston III, "Naturalising values. Organisms and species," in Environmental ethics. Readings in theory and application, (ed.) Louis P Pojman and Paul Pojman (Belmont, CA.: Thomson Wadsworth, 2001), 110.

20 Gustafson, 'A sense of the divine', p. 113.
} 
crucial importance as far as environmental policy is concerned, yet it is dangerous to limit our defence of nature to arguments based on its usefulness to us. ${ }^{21}$

A third paradigm, that is neither anthropocentric nor non-anthropocentric, is needed in judging nature's value. The definition of dignity as a multi-relational term might help to resolve the abovementioned impasse. This would entail distinguishing between the dignity of the entirety - and human dignity and non-human dignity - that correlates with the dignity of the entirety. Dignity of the entirety entails that the cosmos has a multi-relational structure and that the value of nature's parts are known in relation to other parts of nature and according to the values that human beings cherish.

Human dignity ought to correlate with the dignity of the entirety, because the maintenance of the created relational structure is a prerequisite to the realisation of human dignity. Humans have natural rights to utilise natural resources to satisfy human needs, but also the moral responsibility to safeguard the relational structure created by God. Human dignity consists in a person's right to personhood, self-awareness and self-determination, as well as his right to have access to the basic conditions that are required to fulfil his role as caretaker of Gods created order and to live a meaningful life in harmony with God and nature. Such basic conditions include the right to life, physical security, a clean environment and freedom. Personhood, self-awareness and self-determination are not goals in themselves but are created attributes that enable man to serve the needs of other creatures and to enhance the health of the entirety of creation. Freedom must be constrained when an individual exercises these attributes in such a way that he affects the well-being of the entirety.

Non-human dignity is determined by the role which a part of nature plays in the whole complex of relationships in the created order. A distinction needs to be made between inherent value and rights. Animals and plants are inherently valuable because God created them with immanent qualities, yet they are not the sort of things that can have moral rights, because they cannot reciprocate. This does not mean that humans have no duties towards the non-human realm. Nature cannot reciprocate, but it displays what is to be evaluated. Though we cannot bestow rights on individual animals and plants, human beings have the duty to protect the interdependent relational structure created by God, through assessing the value of a part of nature in relation to the whole interdependent structure of the cosmos. Interventions in nature must therefore always be morally and rationally justified and proportional in the sense that the minimum intervention must be used to reach the goals envisaged.

The most important element in protecting the relational structure of creation is to protect life itself. The eating of domesticated animals such as sheep, or experiments on mice, for instance, are morally justified as long as they are not cruel, because they will not harm the well-being of the entirety, but the destruction of species and eco-systems need extraordinary moral justification, since it jeopardises the well-being of the entirety. When species are destroyed, the vitality of life itself is destroyed, since lost species can never be reproduced. Even 'bad kinds' of species play useful roles in population control, in symbiotic relationships, or in providing opportunities for other species. ${ }^{22}$ Ecosystems are

21 Cf. Ned Hettinger, 'Comments on Holmes Rolston's Naturalizing values' in Louis P Pojman and Paul Pojman, (eds.), Environmental ethics. Readings in theory and application, $5^{\text {th }}$ edition (Belmont, CA.: Thomson Wadsworth, 2001), p.122.

22 Holmes Rolston III, 'Environmental ethics: values in and duties to the natural world,' in F Herbert Bormann and Stephen R Kellert, (eds.), Ecology, Economics, Ethics. The broken circle (New Haven: Yale University Press, 1991), 81 . 
important because they are fundamental units of survival that generate and support life, keep selection pressures high, enrich situated fitness, and allow congruent kinds to evolve in their places with sufficient containment. Since ecosystems are selective systems that increase kinds of life, they can never be regarded as merely nominal. They are integral to the created relational structure.

Though the encodification of biotic or non-human rights are not legally tenable, environmental interests can be protected through a combination of environmental laws and the recognition of environmental human rights. Environmental laws must protect nonhuman species and the conditions necessary for their continued existence and ought to provide the basic criteria for making value judgements that determine the role of a nature's part in the entirety. Such laws must become part of international law in order to confront the global ecological crisis. Issues that need to be addressed by environmental laws are: sustainable production; the limitation of pollution to levels that do not exceed the absorption capacities of ecological processes; full public disclosure by governments and private enterprises of the practices followed, as well as the risks involved in toxic waste disposal; the equitable sharing of natural resources; the preservation of biodiversity; redress to victims for violations of their environmental rights and the maintenance of ecosystems and related ecological processes essential for the biosphere. Environmental human rights ought to protect the basic conditions needed by humans to fulfil their role and eke out an existence within the complex relational structure of the entirety. It entails, inter alia, the right of humans to be able to fulfil their roles as caretakers of creation; have access to clean air, water and food; living in a healthy environment and in harmony with existing ecosystems.

\section{Revising the Framework of Human Rights}

Since the concepts of human and non-human dignity have to correlate with the dignity of the entirety, a change in the hierarchy of human rights discourse is needed. Human autonomy cannot be protected if basic conditions for a dignified life are not provided. These can in turn not be provided if the relational structure within which human beings function is not protected.

Although first generation rights have traditionally enjoyed preference above second and third generation rights, it is logical that certain key second and third generation rights should enjoy precedence above some first generation rights, because urgent needs are more immediate necessities than higher goods. Typical first generation rights - such as the right to free trade, freedom of movement, the freedom to practise a profession of your choice, the freedom to possess private property - might in future be limited in order to protect the environment and natural resources. Such limitations of first generation rights are not only necessary for the environment, but also for economic development as such, because unsustainable economies that damage the environment cannot flourish for long.

A recognition of the rights of future generations is also essential, because a consciousness of our inter-generational responsibilities will awaken a desire to save the world for the countless generations of living beings that may come after us. Theologically speaking, the rights of future generations follow from God's covenant with us and our descendants. In the eyes of God the Creator we and our descendants are partners in the same covenant. 
Juridically speaking, future generations are members of our moral community because our social ideal is relevant to them. ${ }^{23}$

Future generations need to enjoy rights of status and not only rights of recognition, because their existence can be reasonably anticipated. The historical continuous nature of communities and the high probability of the existence of future generations are sufficient grounds for affirming rights and responsibilities. Future generations can be said to have anticipatory and presumptive rights, and every present generation therefore has anticipatory obligations. Responsibilities extend not only in space but in time, in a chain of obligation that is passed from one generation to the other. Obligations to future generations are essentially an obligation to produce a desirable state of affairs and promote good living conditions for future generations. Future generation rights would include the right to life, the right not to suffer excessive debts of past generations and the right not to be subjected to the ecological legacy of pollution and environmental degradation. To protect the rights of future generations' development needs to be sustainable. Justice demands that economies should be arranged in a way that ensures efficiency and the anticipated participation of future generations. Growth without limits can no longer be defined as healthy economics.

Care for the environment is probably the most profound obligation that present generations have with regard to future generations, because we thereby promote conditions of good living for the community of the future. Such environmental obligations might include the following:

- Preventing pollution and ecological degradation.

- Promoting conservation.

- Ensuring ecologically sustainable development and a sustainable use of natural resources, while promoting justifiable economic and social development.

- Prohibiting practices such as nuclear proliferation that could jeopardise the opportunities for future generations to come into being.

- Avoiding ecologically irreversible actions that might endanger future generations or deprive them irreversibly for the sake of present generations.

The legal recognition of the abovementioned rights is tenable, because they are definable, measurable and enforceable. Obviously these rights will have to be balanced with other rights, and might also be limited at times, as is the case in all human rights jurisprudence.

\section{Conclusion}

Contemporary human rights discourse over-emphasises the autonomy of the human being at the expense of the relational structure within which human life is embedded. Though it is important to protect the inviolable autonomy of human beings, a multi-relational understanding of dignity that relates human and non-human dignity to the dignity of the entirety is necessary. Human beings are participants in a creational structure whose maintenance is a prerequisite for the protection of individual liberties. Certain human rights such as the right to life and human dignity are inviolable God-given rights that cannot be restricted by the ethical principle of the 'well-being of the entirety'. Yet other human rights such as the right to own property can be limited in order to serve the 'well being of the entirety'. The violability or non-violabality value of non-human entities are, on their part, determined by

23 Cf. Martin Golding, 'Limited obligations to future generations', in Louis P Pojman and Paul Pojman, (eds.), Environmental ethics. Readings in theory and application, $5^{\text {th }}$ edition (Belmont, CA.: Thomson Wadsworth, 2001), p. 361. 
the role they play in the entirety of the created order. In future, human rights jurisprudence will have to balance conflicting rights in terms of the well-being of the entirety. This entails that some third generation rights might need to enjoy precedence over certain first generation rights. It is also important that the rights of future generations should be protected in order to prevent inter-generational apathy that leads to environmental degradation. 